\title{
Using Side-Scan Sonar instrument to characterize and map of seabed for identification target in punggur sea of the Riau islands
}

\author{
Muhammad Zainuddin Lubis ${ }^{1, *}$, Wenang Anurogo ${ }^{1}$, Hanah Khoirunnisa ${ }^{1}$ Sudra \\ Irawan ${ }^{1}$, Oktavianto Gustin ${ }^{1}$, Arif Roziqin ${ }^{1}$ \\ ${ }^{1}$ Department of Informatics Engineering, Geomatics Engineering Batam Polytechnic, Batam Kepulauan Riau, 29461 Indonesia
}

\begin{abstract}
* Corresponding author : zainuddinlubis@polibatam.ac.id
Tel+6281342578087, Office : 778-469856 ext : 2510; fax: +62-778-463620

Received: Jan 15, 2017. Revised : 1 Feb 2017, Accepted: Feb 20, 2017, Published: 1 March 2017

DOI: 10.24273/jgeet.2017.2.1.11

Abstract

Punggur sea has many habitats, object, and structured of seabed with hight tide and wave. Side scan sonar is an underwater acoustic instrument for identification of seabed. This research aims to classify types of seabed and measure seabed identification into the sea water with grain size $(\mathrm{dB})$, location, altitude $(\mathrm{m})$ and target using side scan sonar instrument. This research also uses one types of side scan sonar in one places with 3 line of collecting data to get more variant seabed. Side scan sonar data of $20 \mathrm{~km}$ of side-scan sonar profiling (CM2, C-MAX Ltd, UK) with altitude max $20 \mathrm{~m}$ and a working acoustic frequency of $325 \mathrm{kHz}$ with the zone is taken in the punggur sea $\left(104^{\circ} 08.7102 \mathrm{E}, 1^{\circ} 03.2448 \mathrm{~N}\right.$ until $1^{\circ} 03.3977 \mathrm{~N} 104^{\circ} 08.8133 \mathrm{E}$ ). The data side scan sonar processed using max view software to display the image of the seabed. Results of seabed imagery in the punggur sea on track 1 have Objects found on the ship coordinates $03.3101 \mathrm{~N} 1^{\circ}$ and $104^{\circ}$ $08.7362 \mathrm{E}$ with the highest gain value is $6 \mathrm{~dB}$, altitude $18 \mathrm{~m}$ on ping 75. Linear regression has $\mathrm{y}=0.7016 \mathrm{x}+12.952$ with $\mathrm{R}^{2}=$ $0.4125(41 \%$. Track 2 has target 1 is the sunken object on the seabed, while objects in the form of sand can be seen clearly. Objects found on the sunken object coordinates $1^{\circ} 02.8143 \mathrm{~N}^{\circ}$ and $104^{\circ} 08.5228 \mathrm{E}$ with highest gain value is $9 \mathrm{~dB}$ with altitude $17.7 \mathrm{~m}$ and data ping 69. Linear regression has $y=0.2093+12.577$ with $R^{2}=0.2093(20 \%$. Track 3 has Target 1 is the ship object on the seabed, while objects in the form of sand can be seen clearly. Objects found on the sunken object coordinates $1^{\circ} 02.5817 \mathrm{~N}$ and $104^{\circ} 08.7337 \mathrm{E}$ with the highest gain value is $8 \mathrm{~dB}$ with altitude $16.5 \mathrm{~m}$ and data ping 3984 Linear regression has $y=0.5106 x+12.84$ with $\mathrm{R}^{2}=0.5106(51 \%$. Track 1 has many targets identification results compared Track 2 and 3.
\end{abstract}

Keywords: Punggur Sea, Seabed Identification , Side Scan Sonar (SSS), Gain (dB), Altitude (m).

\section{Introduction}

Punggur sea is the part of the Riau Islands in Indonesia. Generally Punggur sea still rarely done research on the identification of seabed using the acoustic wave technology. Acoustic wave technology is a hydroacoustic method are increasingly being used in all kinds of aquatic ecosystems in order to acquire detailed information about stock estimation about fish abundance and seabed identification (Lubis and Wenang 2016).

The acoustic instrument has sound waves through the medium of water that will be backscatter by objects in the water column and seabed. That backscatter on waveform characteristics can be Analyzed to get information base object seabed. Side Scan Sonar is acoustic instruments can be transmitted pulse by the beam or Sound Waves To the left and right side with a specific frequency (M edwin and Clay 1998). Theaim of this hydroacoustic survey was to estimate the total biomass of fish in Sikka regency waters using long transects sampling patterns and calculation methods of biomass in hydroacoustic method (Lubis and Pujiyati, 2016, Lubis et al., 2016). Research on the seabed using side scan sonar has been done, such as detection and interpretation on the seabed using side scan sonar instruments (Sari and Manik 2009).

Side scan data are traditionally displayed as gray images and interpreted with some knowledge of the side-scan system and the sea-floor geology, together with some independent observations (socalled "ground truth") (Somers et al., 1978). the sonar data are preprocessed to correct for the influences of the sonar beam pattern and timevarying gain (TVG) (Capus et al., 2004 and Diaz et al., 2002) This paper seeks to consider about identification of the target position on the outcome of the identification image of the seabed, the value of Gain $(\mathrm{dB})$, altitude $(\mathrm{m})$, beam sweep area of side 
scan sonar, and object identification in punggur sea of the Riau Islands in Indonesia.

\section{Materials and Method}

The research was conducted in December 2016 in the punggur sea of the Riau Islands in Indonesia. $\left(104^{\circ} 08.7102 \mathrm{E}, 1^{\circ} 03.2448 \mathrm{~N}\right.$ until $1^{\circ} 03.3977 \mathrm{~N}$ $104^{\circ} 08.8133 \mathrm{E}$ ) (Fig 2). Tracking of cruise side scan sonar and research location have 3 tracking line (Fig 2).

Acoustic data acquisition was done using instruments CM2 Side Scan Sonar system was used to survey the Modiolus bed off the Point of Ayre. The side-scan-sonar tow fish was set at high frequency $(325 \mathrm{kHz})$ and with a total swath width of $200 \mathrm{~m}$ (Fig 1).

The tow fish was towed at a speed of approximately 4 Knots at an altitude of 12-18 m above the seabed. The broad-scale surface sediments characterization was performed using a high-resolution C-Max CM2 Side Scan Sonar, providing digital side-scan sonar imagery. The system allowed the user to operate it under dual acoustic signal frequencies, at $325 \mathrm{KHz}$.

The system gain $\mathrm{G}$ includes the effects of timevaried gain and correlation as well as the transducer pressure-voltage gains and amplifier gains. The 12bit value is then compressed into a coded 8-bit value before being stored. Our estimate of $G$ is probably accurate to within $6 \mathrm{~dB}$; this is one of the largest sources of error in our calculations.This Time-Varied Gain (TVG) is used to compensate for the decreasing intensity of the backscattered signal and keeps the signal output within the dynamic range of the recorder. The TVG is not continuous but is actually produced in a series of $1.5-\mathrm{dB}$ steps (Mitchell \& Somers 1989). The time-varied gain function (ignoring the step-like nature of the TVG) is approximated by:

TVG $=-\left(\mathrm{DB}-30 \log 10\right.$ (range) $-8.2 \times 10^{-4}$ range)90/DB (dB)

where DB is a constant and range is in meters. The voltage ratio is

$$
\text { TVG }(\text { range })=10^{\mathrm{TVG} / 20}
$$

To attenuate sidelobes in the correlator output, the rectangular FM pulse is correlated with an amplitude shaded (Hamming in Mitchell \& Somers 1989) reference, rather than with a matched rectangular pulse. The equation of this Hamming function in (Mitchell \& Somers 1989) is given by:

Shade $(t)=0.54+0.46 \cos (2 \pi t / T)$ for the interval $\mathrm{T} / 2<\mathrm{t}<\mathrm{T} / 2$

Where T is the pulse length (usually $2 \mathrm{~s}$ ), showed in Fig 3.
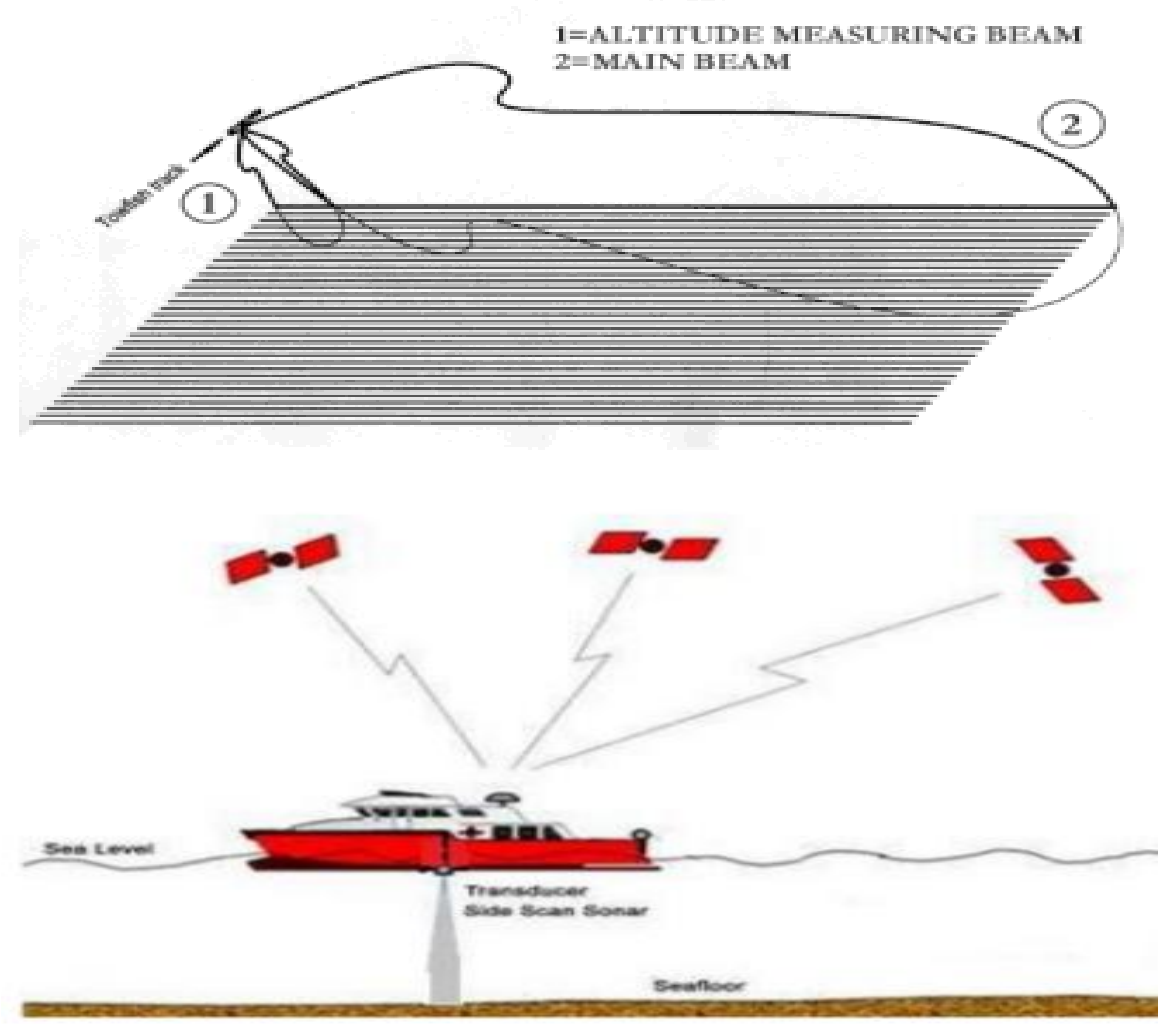

Fig. 1. Altitude measuring and main beam of Side Scan Sonar C-Max CM2 Sonar System and side sonar Scheme in acquisitions data. 


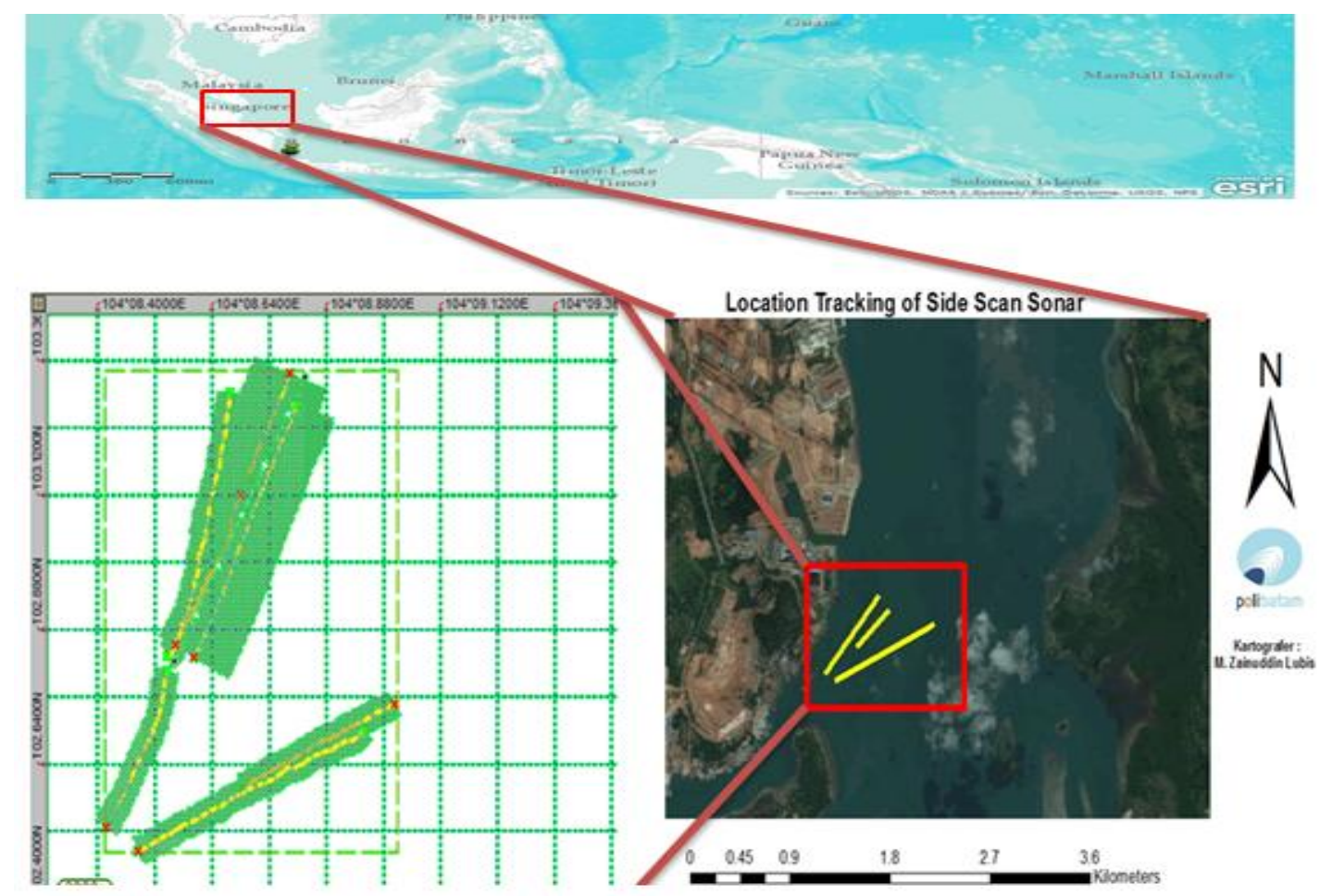

Fig 2. Tracking of cruise side scan sonar and research location in Punggur sea punggur sea of the Riau Islands in Indonesia.

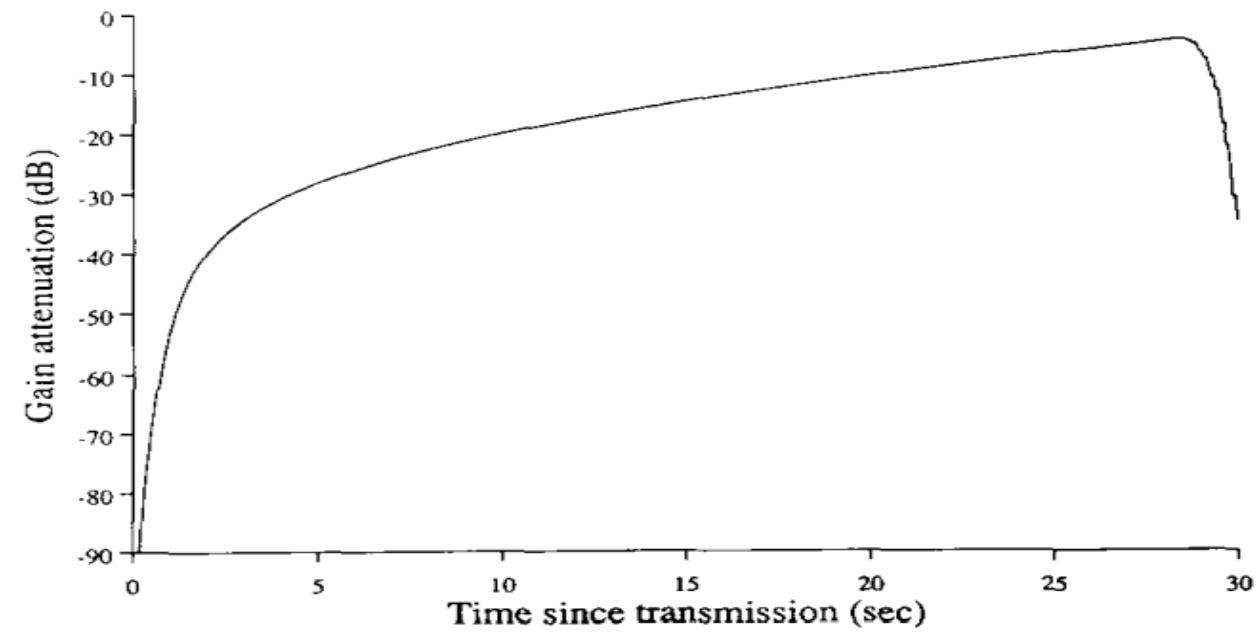

Fig 3. Signal attenuation due to time-vaned gain, correlation with a shaded pulse and eclipsing.

\section{Result and discussion}

\subsection{Image Classification Sediment}

Image classification of sediment carried by the qualitative analysis, which is to distinguish the type of sediment is based on the results of the scan sonar imagery. The results of C-Max CM2 Side Scan Sonar (SSS) is an image with a high frequency of $325 \mathrm{kHz}$.
Max-view capable of displaying in Fig 4, Total ping 2336 pings, measure selected record is $362 \mathrm{~m}$, and the distance between pins is $13900 \mathrm{~km}$ (Fig 4). This happens because of side -Max CM2 Side Scan Sonar (SSS) has a short duration pulse with simultaneous observations (MacLennan and Simmonds 2005). Target, time, location, ping, gain, and altitude value on track 1, Punggur sea showed in Table 1. 

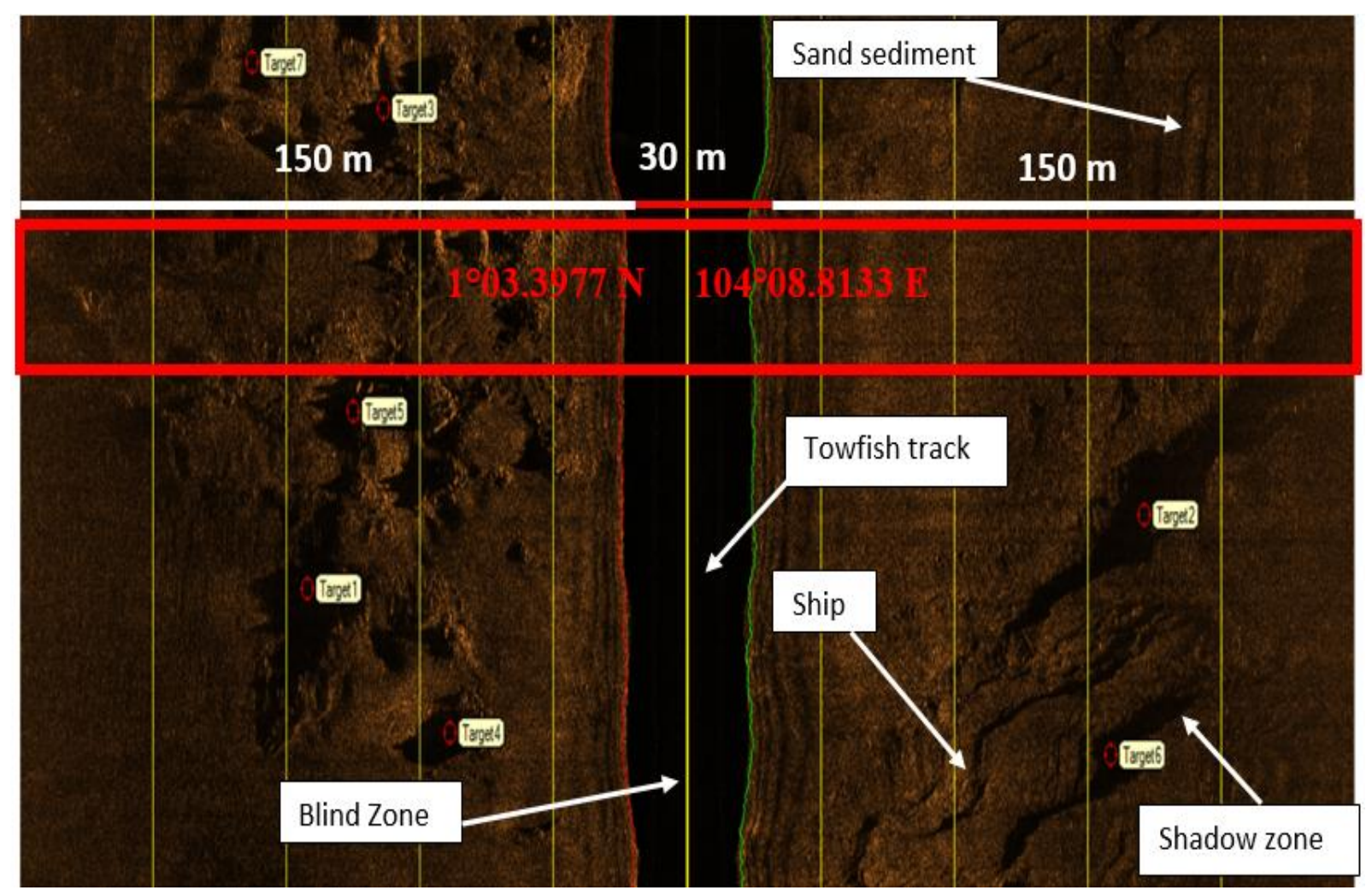

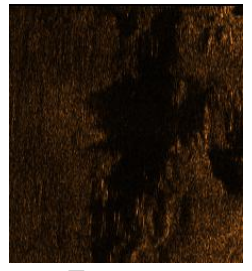

Target 1

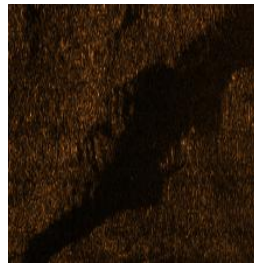

Target 2

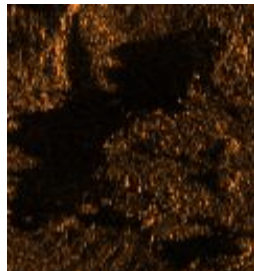

Target 3

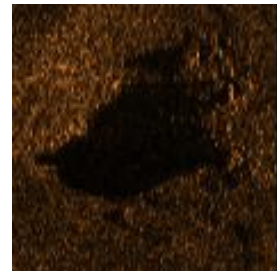

Target 4

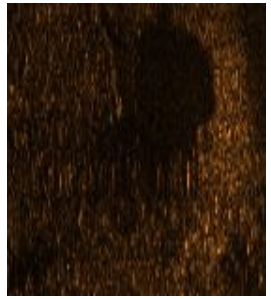

Target 5

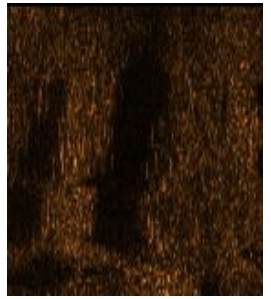

Target 6

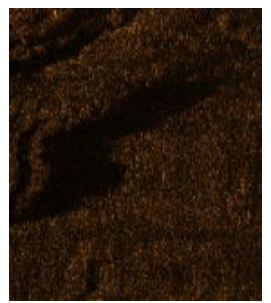

Target 7

Fig 2. Image classification and position target 1- 7 on sediment track 1, Punggur sea

Table 1. Target, time, location, ping, gain, and altitude value on track 1, Punggur sea

\begin{tabular}{ccccccc}
\hline Target & Time & Latitude & Longitude & Ping & $\begin{array}{c}\text { Gain } \\
(\mathrm{dB})\end{array}$ & $\begin{array}{c}\text { Altitude } \\
(\mathrm{m})\end{array}$ \\
\hline 1 & $13: 43: 12 \mathrm{AM}$ & $1^{\circ} 03.2448 \mathrm{~N}$ & $104^{\circ} 08.7102 \mathrm{E}$ & 417 & 3 & 13.8 \\
\hline 2 & $13: 43: 20 \mathrm{AM}$ & $1^{\circ} 03.2109 \mathrm{~N}$ & $104^{\circ} 08.8057 \mathrm{E}$ & 458 & 1 & 14.5 \\
\hline 3 & $13: 44: 05 \mathrm{AM}$ & $1^{\circ} 03.2992 \mathrm{~N}$ & $104^{\circ} 08.7471 \mathrm{E}$ & 678 & 4 & 18 \\
\hline 4 & $13: 42: 56 \mathrm{AM}$ & $1^{\circ} 03.2207 \mathrm{~N}$ & $104^{\circ} 08.7180 \mathrm{E}$ & 339 & 5 & 14.5 \\
\hline 5 & $13: 44: 57 \mathrm{AM}$ & $1^{\circ} 03.3977 \mathrm{~N}$ & $104^{\circ} 08.8133 \mathrm{E}$ & 931 & 2 & 13.8 \\
\hline 6 & $13: 44: 11 \mathrm{AM}$ & $1^{\circ} 03.3101 \mathrm{~N}$ & $104^{\circ} 08.7362 \mathrm{E}$ & 705 & 6 & 18.1 \\
\hline 7 & $13: 42: 53 \mathrm{AM}$ & $1^{\circ} 03.1832 \mathrm{~N}$ & $104^{\circ} 08.7875 \mathrm{E}$ & 331 & 3 & 14.8 \\
\hline
\end{tabular}




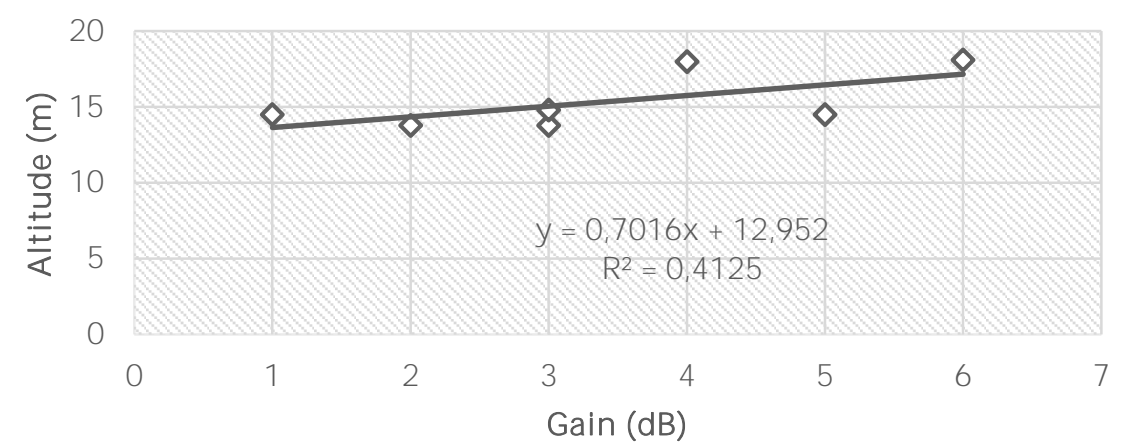

$\diamond$ Series1 Linear (Series1)

Fig 3. Linear regression of Gain (dB) with Altitude $(\mathrm{m})$ on track 1, Punggur sea

Fig 2 shows the image of seabed sediments that have a target number of 7 . Target 6 is the object of the sunken ship on the seabed, while objects in the form of sand can be seen clearly. Objects found on the ship coordinates $03.3101 \mathrm{~N} 1^{\circ}$ and $104^{\circ} 08.7362$ $E$ with the highest gain value is $6 \mathrm{~dB}$ with altitude 18 meter. The port (right side) seen the entrenchment of a lighter color. Their excavation led to differences in texture, roughness, and slope of the seabed sediments. Besides excavation occurred on the seabed allegedly causing sediment coarser grain size larger particles beneath it lifted up. According to Urick (1983) grain size, scale sediment surface roughness and slope significant variations can be the important role in the acoustic response. Linear regression has $y=0.7016 x+12.952$ with $R^{2}=0.4125$, by looking at the equation it is clear that the correlation between the gain and the altitude at the track 1 by $41 \%$ with alpha is 5 (Fig 3). Colliers and Brown (2005), said that the phenomenon of backscattering seabed has relationships with the roughness. The more coarse sediment would reflect highest backscatter. Image classification and position target 1- 6 on sediment track 2 showed in Fig 4.

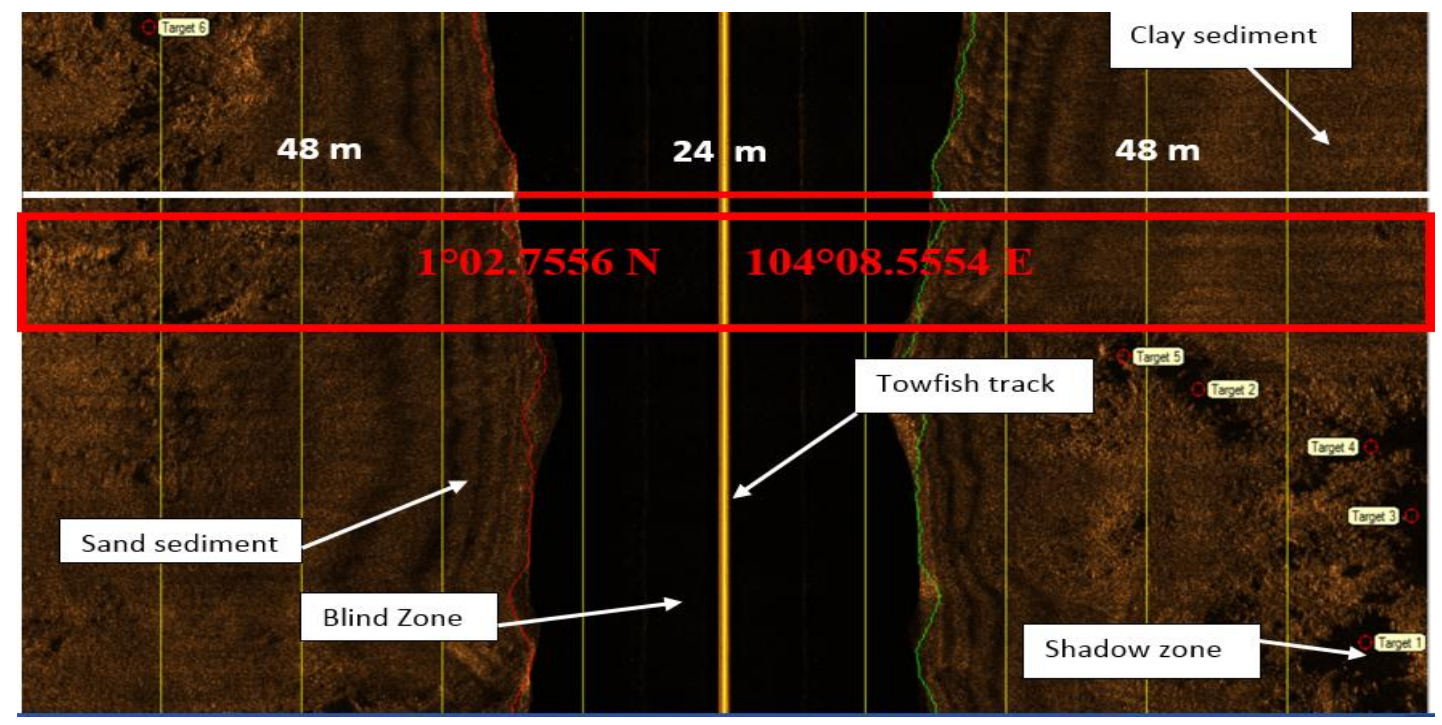

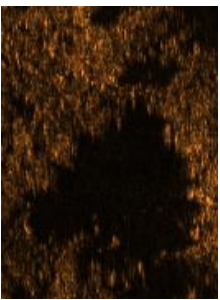

Target 1

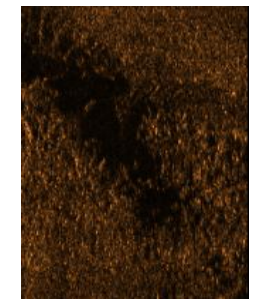

Target 2

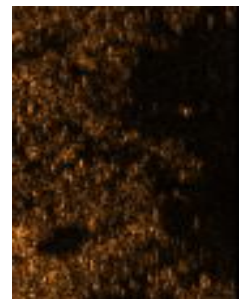

Target 3

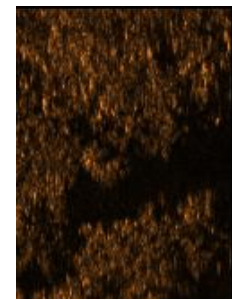

Target 4

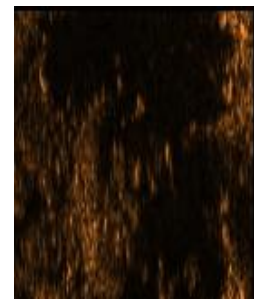

Target 5

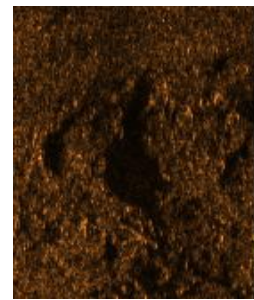

Target 6

Fig 4. Image classification and position target 1- 6 on sediment track 2, Punggur sea 
Table 2. Target, time, location, ping, gain, and altitude value on track 2, Punggur sea

\begin{tabular}{ccccccc}
\hline Target & Time & Latitude & Longitude & Ping & Gain (dB) & $\begin{array}{c}\text { Altitude } \\
(\mathrm{m})\end{array}$ \\
\hline 1 & $14: 28: 13 \mathrm{AM}$ & $1^{\circ} 02.8143 \mathrm{~N}$ & $104^{\circ} 08.5228 \mathrm{E}$ & 69 & 9 & 17.7 \\
\hline 2 & $14: 28: 28 \mathrm{AM}$ & $1^{\circ} 02.7913 \mathrm{~N}$ & $104^{\circ} 08.5229 \mathrm{E}$ & 283 & 8 & 13.3 \\
\hline 3 & $14: 28: 25 \mathrm{AM}$ & $1^{\circ} 02.7981 \mathrm{~N}$ & $104^{\circ} 08.5178 \mathrm{E}$ & 178 & 4 & 14.5 \\
\hline 4 & $14: 28: 20 \mathrm{AM}$ & $1^{\circ} 02.8050 \mathrm{~N}$ & $104^{\circ} 08.5184 \mathrm{E}$ & 232 & 6 & 15.3 \\
\hline 5 & $14: 28: 51 \mathrm{AM}$ & $1^{\circ} 02.7556 \mathrm{~N}$ & $104^{\circ} 08.5554 \mathrm{E}$ & 17 & 7 & 14.8 \\
\hline 6 & $14: 28: 30 \mathrm{AM}$ & $1^{\circ} 02.7880 \mathrm{~N}$ & $104^{\circ} 08.5253 \mathrm{E}$ & 583 & 8 & 16.4 \\
\hline
\end{tabular}

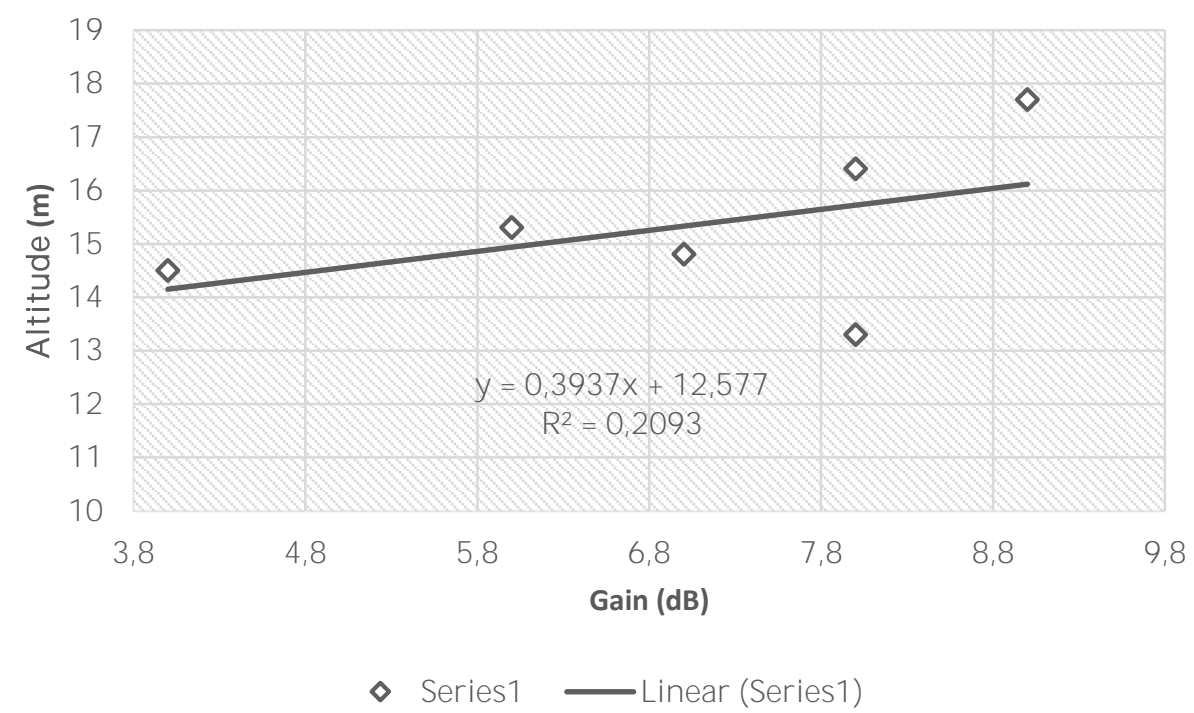

Fig 5. Linear regression of Gain (dB) with Altitude $(m)$ on track 2, Punggur sea

Fig 4 shows the image of seabed sediments that have a target number of 6 . Target 1 is the sunken object on the seabed, while objects in the form of sand can be seen clearly. Objects found on the sunken object coordinates $1^{\circ} 02.8143 \mathrm{~N}{ }^{\circ}$ and $104^{\circ} 08.5228 \mathrm{E}$ with highest gain value is $9 \mathrm{~dB}$ with altitude $17.7 \mathrm{~m}$ and data ping 69 . The port (right side) seen the entrenchment of a dark color (shadow zone). According to (Kenny et al., 2003) sweep of side scan sonar can produce mosaics, geological and sedimentology features that are easily recognized and interpreted qual itatively so as to provide information about the dynamics of the seabed.

Based on data from the movement of side scan sonar found on the sensor pitch movements occur up to 15 degrees from a standstill 0 degrees roll movements occur up to 10 degrees from its current position silent 0 degrees. Unlike the sediment mud, sand sediment has particularly rough look more like in Fig. 4.

Linear regression has $y=0.2093+12.577$ with $R^{2}$ $=0.2093$, by looking at the equation it is clear that the correlation between the gain and the altitude at the track 2 by $20 \%$ with al pha is 5 (Fig 5). Differences in sediment forming material thought to affect the image side scan sonar that biogenic sand looks more rugged. Effect of seabed slope in the Punggur sea will also affect the condition of sediment due to gravitational forces. However, based on the image side scan sonar can be seen clear differences in texture and roughness on the sand sediments, biogenic sand and clay. Image classification and position target 1- 5 on sediment track 2 showed in Fig 6. 


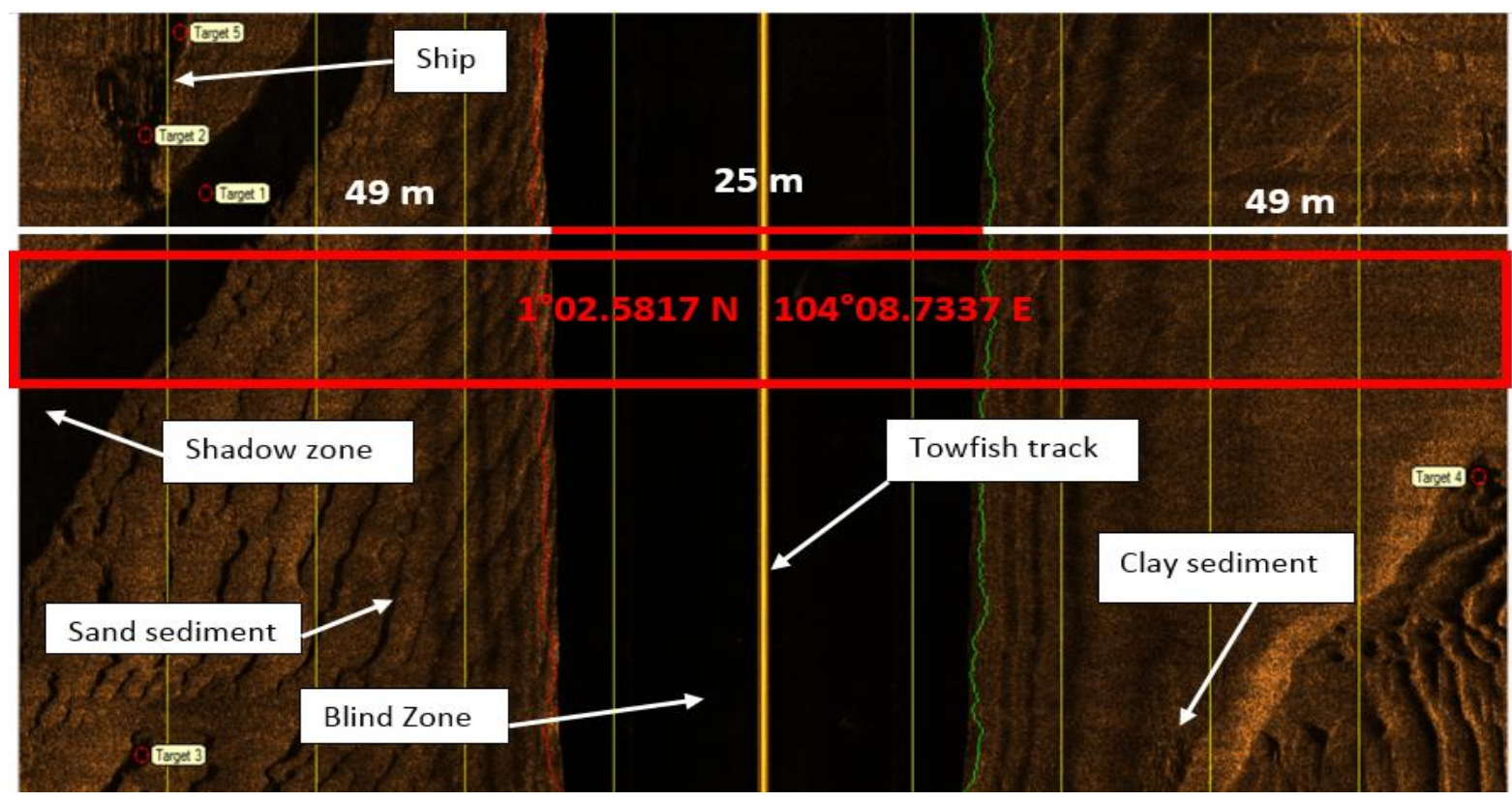

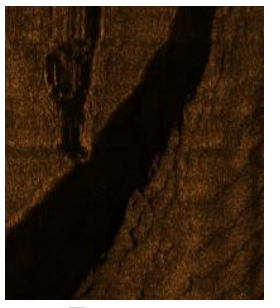

Target 1

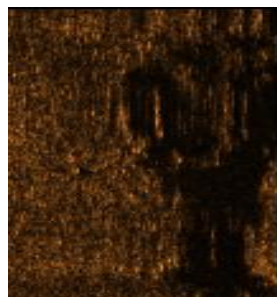

Target 2

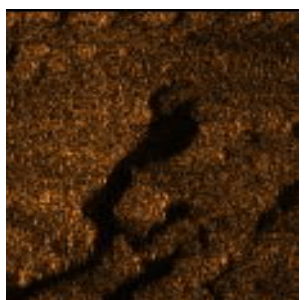

Target 3

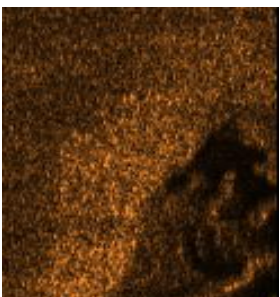

Target 4

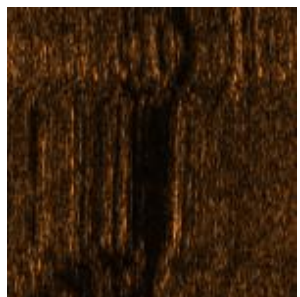

Target 5

Fig 6. Image classification and position target 1- 5 on sediment track 3, Punggur sea

Table 3. Target, time, location, ping, gain, and altitude value on track 3, Punggur sea

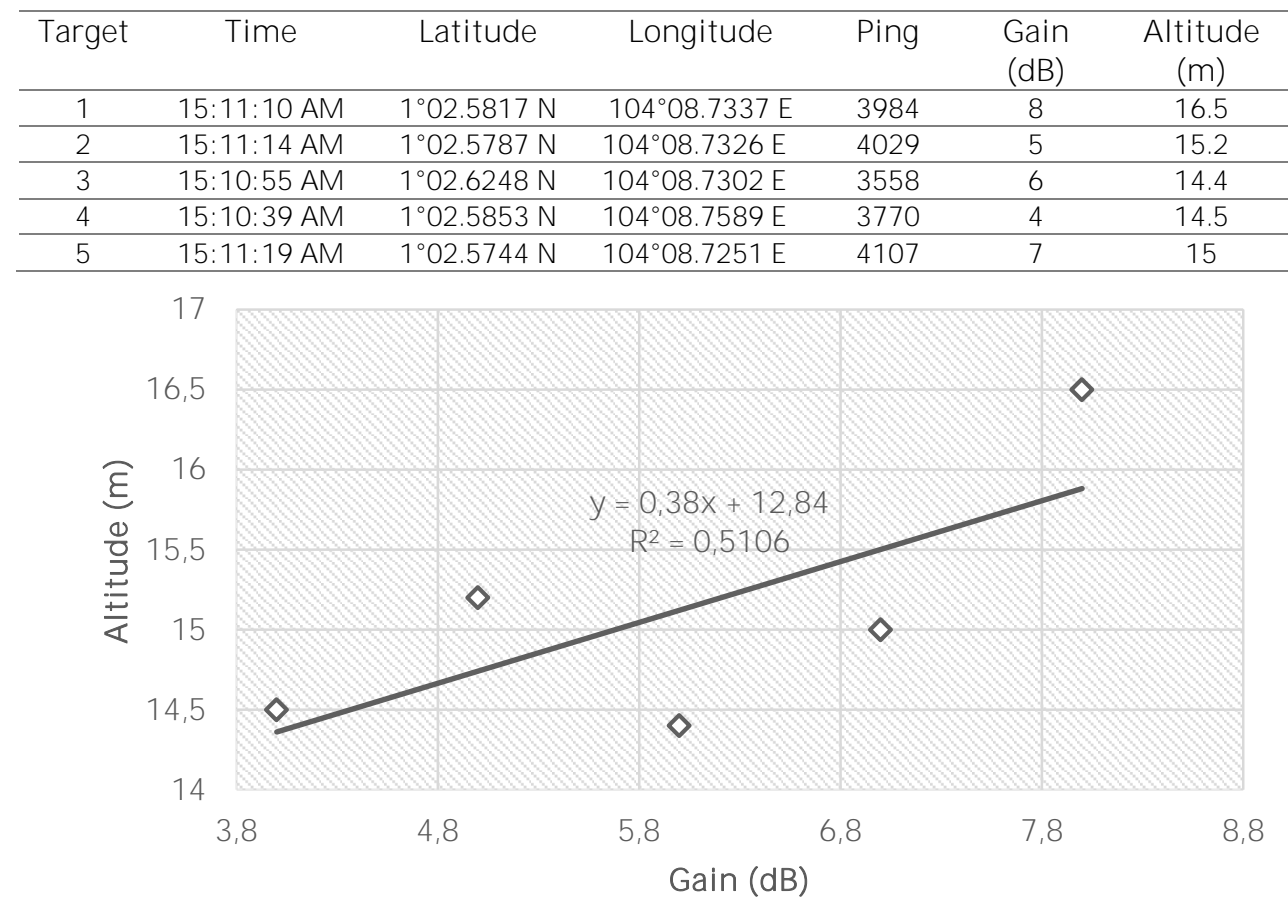

$\diamond$ Series1 Linear (Series1)

Fig 7. Linear regression of Gain (dB) with Altitude (m) on track 3, Punggur sea 
Fig 4 shows the image of seabed sediments that have a target number of 6 . Target 1 is the ship object on the seabed, while objects in the form of sand can be seen clearly. Objects found on the sunken object coordinates $1^{\circ} 02.5817 \mathrm{~N}$ and $104^{\circ} 08.7337 \mathrm{E}$ with the highest gain value is $8 \mathrm{~dB}$ with altitude $16.5 \mathrm{~m}$ and data ping 3984. Linear regression has $\mathrm{y}=$ $0.5106 x+12.84$ with $R^{2}=0.5106$, by looking at the equation it is clear that the correlation between the gain and the altitude at the track 3 by $51 \%$ with al pha is 5 (Fig 7). The Blind zone is shadow zone in tracking figure of side scan sonar instrument. The influence factor of width blind zone will be has image seabed identification not be specific. The influence width of the blind zone so small in the area is result sweep of side scan sonar instrument (Figure 2, 4, and 6).

\section{Conclusion}

Research in Punggur sea using C-Max CM2 Side Scan Sonar system with a frequency of $325 \mathrm{kHz}$, obtained on the seabed is the sediment of sand than clay and find the shipwreck that sunk in Track 1 and Track 3.

Highest gain value is on Line 2 in the coordinates $102.8143^{\circ} \mathrm{N} 08.5228^{\circ}$ and $104^{\circ} \mathrm{E}$, and is the lowest That is on Track 1 at coordinates $03.3101 \mathrm{~N} 1^{\circ}$ and $104^{\circ} 08.7362$ E. Relations between Value Gain And heights That have the highest correlation on track $3(51 \%)$. Track 1 has many targets identification results compared Track 2 and 3. The influence factor of width blind zone is beam pattern of side scan sonar instrument with altitude from position of towfish.

\section{Acknowledgements}

This work was funded was financed by Marine Instrumentation and Application Club (MIAC) member: Fikriansyah, Dirgan T, Adit, Fajar, Ganda, Sandi, Bayu, Andrew, Diaz, Perdi, Batam Polytechnic, Indonesia and PT Hidronav Tehnikatama, Indonesia.

\section{References}

Capus, C., Ruiz, I. T., \& Petillot, Y. 2004. Compensation for changing beam pattern and residual tvg effects with sonar altitude variation for sidescan mosaicing and classification. In 7th. Eur. Conf. Underwater Acoustics, Delft, The Netherlands.

Collier JS dan CJ Brown. 2005. Correlation of Sidescan Backscatter with Grain Size Distribution of Surficial Seabed Sediments. Journal of marine geology, geochemistry and geo physhics (214). 431-449.

Diaz, D., Cuevas, K., Buchanan, M., Gordon, S., \& Perret, W. S. 2002. Side scan sonar in oyster management. In OCEANS'02 MTS/IEEE (Vol. 1, pp. 141-145). IEEE.

Kenny AJ, Cato I, Desprez M, Fader G, Schüttenhelm RTE dan Side J. 2003. An Overview of Seabed Mapping Technologies in the Context of Marine Habitat Classification. ICES Journal of Marine Science (60): 411-418.

Lubis, M. Z., \& Anurogo, W. 2016. Fish stock estimation in Sikka Regency Waters, Indonesia using Single Beam
Echosounder (CruzPro fish finder PcFF-80) with hydroacoustic survey method. Aceh Journal of Animal Science, 1(2).

Lubis, M. Z., S. Pujiyati. 2016. Detection backscatter value of mangrove crab (Scylla sp.) using Cruzpro Fishfinder Pcff- 80 hydroacoustic instrument. Journal of Biosensor and Bioelectronic, 7(2): 1000205.

Lubis, M. Z., Wulandari, P. D., Mujahid, M., Hargreaves, J., \& Pant, V. 2016. Echo Processing and Identifying Surface and Bottom Layer with Simrad Ek/Ey 500. Journal of Biosensors and Bioelectronics, 7(3), 1000212.

MacLennan DN dan Simmonds EJ. 2005. 2th Fisheries Acoustic: Theory andPractice. Oxford (UK): Blackwell Science.

Medwin, H., \& Clay, C. S. 1998. Fundamentals of Acoustical Oceanography Academic. New York, 24.

Medwin, H., \& Clay, C. S. 1998. Fundamentals of Acoustical Oceanography Academic. New York, 24.

Mitchell, N. C., \& Somers, M. L. 1989. Quantitative backscatter measurements with a long-range sidescan sonar. IEEE Journal of Oceanic Engineering, 14(4), 368-374.

Sari SP dan HM Manik. 2009. Deteksi dan Interpretasi Target di Dasar Laut Menggunakan Instrumen Side scan sonar. Seminar Nasional Teori dan Aplikasi Teknologi Kelautan. 25-30.

Somers, M. L., Carson, R. M., Revie, J. A., Edge, R. H., Barrow, B. J., \& Andrews, A. G. 1978. GLORIA II-An improved long range sidescan sonar. In Oceanology International (Vol. 78, pp. 16-24).

Urick RJ. 1983. Principles of Underwater Sound. 3rd ed. New York (US): Mc-Graw-Hill. 